\title{
Evaluation of the Utility of the Random Amplified Polymorphic DNA Method and of the Semi-Specific PCR to Assess the Genetic Diversification of the Gerbera jamesonii Bolus Line
}

\author{
Zbigniew Rusinowski and Olga Domeradzka \\ Department of Ornamental Plants, Warsaw School of Life Sciences, Faculty of Horticulture and Landscape Architecture, \\ Warsaw University of Life Sciences, Nowoursynowska 159, 02776 Warsaw, Poland \\ Correspondence should be addressed to Zbigniew Rusinowski, zbyszek@rusinowski.pl
}

Received 13 December 2011; Accepted 3 January 2012

Academic Editor: Kaye Spratt

Copyright ( 2012 Z. Rusinowski and O. Domeradzka. This is an open access article distributed under the Creative Commons Attribution License, which permits unrestricted use, distribution, and reproduction in any medium, provided the original work is properly cited.

\begin{abstract}
An attempt was made to evaluate the utility of a method which employs semi-specific PCR using partially specific primers for the coding sequence (ET) at the exon-intron contact and of the RAPD method to identify eight Polish cultivars of gerbera. It was demonstrated that the PCR method which employs semi-specific primers is as simple and economical as the RAPD method, simultaneously the images of the multiplied by means of the semi-specific PCR method DNA fragments are more complex and polymorphic than those obtained through the RAPD method. The studies of the genetic diversification of Gerbera cultivars employing the aforementioned methods made it possible to conduct a concentration analysis and evaluation of the genetic distance between the lines, manifesting at the same time the superiority of the semi-random PCR method. Moreover, it transpired that the use of mixtures of RAPD primers not always leads to an increase of the number of generated polymorphic bands.
\end{abstract}

\section{Introduction}

At the turn of the 21st century, identification of cultivars and protection of breeders' rights became an important issue, especially when it is impossible to tell them apart by their morphologic features such as, for example, the shape of seeds, bulbs, or cuttings [1]. It frequently occurs that cultivars, phenotypically similar, for example, whose flowers are of the same color stem from different breeding companies, and may be confused. Thanks to modern methods based on DNA analysis techniques allow to identify and select plants bearing desired features [2]. The current methods quickly enable us to profoundly analyze of consanguinity and pedigree and to determine the value of breeding material [3]. RAPD is one of the methods recommended to identify the cultivars of Gerbera jamesonii $[4,5]$.

Gerbera has the current methods quickly allows for analysis of an important position in the floral market for several years. Each year new cultivars are introduced; they are to attract customers not only with their color but also with their shape and the size of their inflorescence and to attract growers with higher yield and tolerance to growing conditions. The preferences of Polish customers as for cut flowers have changed in recent years, and, after a shorttermed stagnation which affected the gerbera market, we may witness a slow but significant rise interest among those who purchase these species.

The present paper attempts to compare the usability of the RAPD method and semi-specific PCR with the use of partially specific primers for the coding sequence lying on the exon-intron junction, never hitherto applied in the case of the gerbera cultivar to identify eight Polish cultivars bred by the Pętoś company.

\section{Materials and Methods}

The experiment was conducted in the years 2004-2006 at the Faculty of Horticulture and Landscape Architecture at the Warsaw University of Life Sciences (Wydział Ogrodnictwa i Architektury Krajobrazu SGGW) in Warsaw. The material 
TABle 1: Primers used to evaluate the consanguinity of the G. jamesonii cultivars with the nucleotide sequence, total bands number, number of differentiating bands, and the contribution of differentiating bands expressed as a percentage.

\begin{tabular}{lccc}
\hline Primer code & Nucleotide sequence of the primers & Total bands number & Contribution of differentiating bands (\%) \\
\hline A2 & $5^{\prime}$-TGCCGAGCTG-3' & 5 & $40.0 \%$ \\
C11 & $5^{\prime}$-AAAGCTGCGG-3' & 10 & $20.0 \%$ \\
D5 & $5^{\prime}$-TGAGCGGACA-3' & 7 & $28.6 \%$ \\
D8 & $5^{\prime}$-GTGTGCCCCA-3' & 8 & $25.0 \%$ \\
D11 & $5^{\prime}$-AGCGCCATTG-3' & 7 & $28.6 \%$ \\
G12 & $5^{\prime}$-CAGCTCACGC-3' & 9 & $33.3 \%$ \\
\hline
\end{tabular}

was delivered by the Pętoś "Specjalistyczny Zakład Ogrodniczy Bartoszyce" company. Eight new Polish plant cultivars raised by the aforementioned company were used (Amelia, Bartoszyce, Bolesławiec, Delfin, Kraków, Kreta, Safona, Samuraj).

To isolate the DNA young leaves were used as source. Two DNA isolation methods were employed. The isolation by means of Genomic Mini AX plant kits from the A\&A Biotechnology company and the $\mathrm{CTAB}$ procedure after Murray and Thompson [6].

In the RAPD experiments, the amplification program consisted of $40 \mathrm{~m}$ cycles; initial denaturation $72^{\circ}-5^{\prime}$, denaturation $94^{\circ}-1^{\prime}$, attachment $39^{\circ}-1^{\prime}$, final temperature $72^{\circ}-2^{\prime}$ [7]. The composition of the amplification was performed in two-stages mixture PCR whose total volume equaled $25 \mu \mathrm{L} 15.95 \mu \mathrm{L}$ of water dd (miliQ), $2 \mu \mathrm{L}$ of $\mathrm{MgCl}^{2}, 2.5 \mu \mathrm{L}$ of buffer $10 \mathrm{x}, 1.25 \mu \mathrm{L}$ of $\mathrm{dNTP}, 1 \mu \mathrm{L}$ of primer, $0.3 \mu \mathrm{L}$ of TAQ polymerase DNA, and $2 \mu \mathrm{L}$ of tested DNA (approx. $10 \mathrm{ng} / \mu \mathrm{L})$.

In the case of semi-specific primers, the DNA amplification was two stage. At the first stage for the 15 nucleotide primers in comparison to the 18 nucleotide primers, the primer attachment temperature was by $10^{\circ}$ higher $\left(50-60^{\circ}\right)$ at the second stage it was by $10^{\circ}$ lower $\left(64-54^{\circ}\right)$ the attachment time was 1 minute. In both cases this amplification program was used: denaturation $94^{\circ}-40^{\prime \prime}$, lengthening of the DNA chains in $72^{\circ}-2^{\prime}$, multiplication completed in $72^{\circ}-5^{\prime}$, at the second stage next denaturation followed in $94^{\circ}-40^{\prime \prime}$, lengthening of the DNA chains in $72^{\circ}-2^{\prime}$, and final multiplication $72^{\circ}-10$ [8]. The composition of the mixture of the semispecific PCR by Rafalski [8], of which volume requaled $20 \mu \mathrm{L}, 10 \mu \mathrm{L}$ of water dd (miliQ), $2 \mu \mathrm{L}$ of $\mathrm{MgCl}_{2}, 2 \mu \mathrm{L}$ of buffer $10 \mathrm{x}$ with ammonium sulfate, $0.5 \mu \mathrm{L}$ of $\mathrm{dNTP}, 3 \mu \mathrm{L}$ of primer, 1 TAO unit of DNA polymerase, and $2 \mu \mathrm{L}$ of the tested DNA (approx. $10 \mathrm{ng} / \mu \mathrm{L}$ ). Reagents from MBI Fermentas were used, with the exception of dNTP bought from Invitrogen. The electrophoretic separation was conducted on $1.5 \%$ agarose gel in TAE $1 \mathrm{x}$ buffer with addition of $10 \mu \mathrm{L}$ $0.01 \%$ of ethidium bromide. The visualization took place in the UV light. The experiment was documented with the help of a monochromatic camera and software by Biometra BioDell.

The genetic similarity of the analyzed cultivars was computed by means of the Nei and Li formula [9] of the mean UPGMA connections. The concentration analysis was performed with the use of the NTSYS-pc program, v. 2.1.

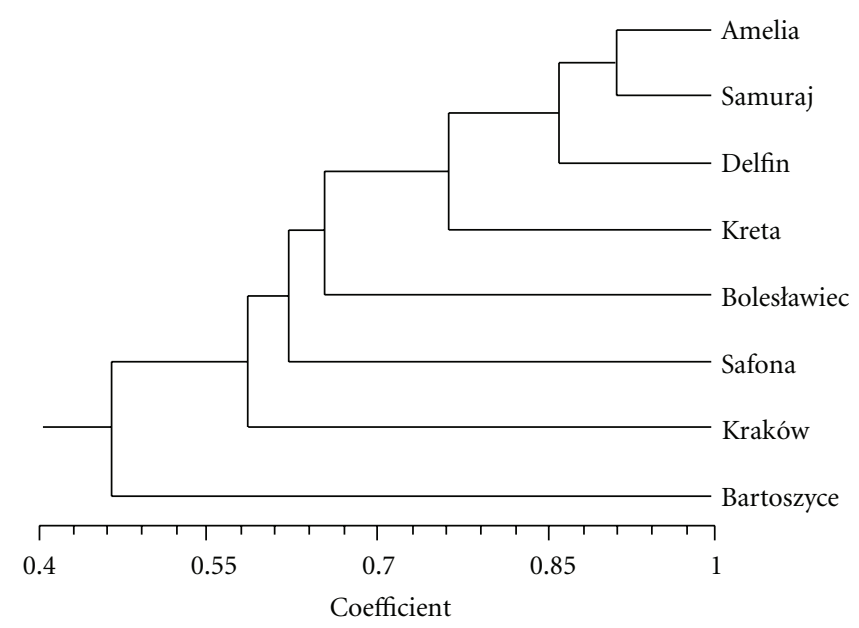

Figure 1: Similarity diagram of the tested G. jamesonii cultivars comuted from the mean connections method (UPGMA) and from a RAPD analysis of 19 DNA fragments.

\section{Results}

3.1. The Diversification Characteristics of Eight G. jamesonii Cultivars by Means of Selected RAPD Primers. The usability of twenty 10-nucleotide RAPD primers prepared according to the operon nomenclature in the DNA Sequence-forming Laboratory at the Institute of Biochemistry and Biophysics PAN was tested.

The RAPD technique was used to differentiate eight gerbera cultivars. For the purpose of the study, 6 out of the 20 tested primers were chosen: those which generated the highest total number of bands and the highest number of differentiating bands (Table 1).

The primer which gave the highest percentage of differentiating bands (40\%) generating the lowest number of total bands was the A2 primer. Primer C11, which generated the highest number of bands (10), gave relatively small, equals $20 \%$, contribution of differentiating bands. The other primers rendered on average $28.9 \%$ polymorphic bands (Figure 3).

The evaluation of genetic similarity of the cultivars was based on the analysis of 19 DNA fragments obtained from experiments using the RAPD method (Figure 1). The genetic distance coefficients between the tested lines were computed 
TABle 2: Primers used to evaluate the consanguinity among the cultivars of G. jamesonii with the nucleotide sequence, total bands number and the fraction of polymorphic bands in percentage.

\begin{tabular}{lcc}
\hline Primer code & $\begin{array}{c}\text { Total bands } \\
\text { number }\end{array}$ & $\begin{array}{c}\text { Participation of differentiating } \\
\text { polymorphic bands (\%) }\end{array}$ \\
\hline ET $1 / 18$ & 6 & $66.6 \%$ \\
ET 2/18 & 11 & $90.9 \%$ \\
ET 3/18 & 4 & $25 \%$ \\
ET 4/18 & 4 & $75 \%$ \\
ET 5/18 & 9 & $33.3 \%$ \\
ET 6/18 & 18 & $100 \%$ \\
ET 31/15 & 0 & 0 \\
ET 32/15 & 10 & $80 \%$ \\
ET 33/15 & 3 & 0 \\
ET 34/15 & 6 & $50 \%$ \\
ET 35/15 & 9 & $55.5 \%$ \\
ET 36/15 & 8 & $62.5 \%$ \\
\hline
\end{tabular}

from the RAPD experiments and ranged from 0.09 to 0.62 (the average 0.37 ). It had been computed that the minimum genetic distance is between the Amelia and Samuraj cultivars (0.09), and the maximum distance separates the Bolesławiec from the Bartoszyce cultivar and the Bartoszyce from the Safona cultivar (0.62).

3.2. The Evaluation of the Differentiation of Gerbera sp. Cultivars by Means of Semi-Specific PCR. To distinguish the eight G. jamesonii cultivars, the utility of 12 semi-conservative primers was evaluated; those primers were partially specific for the coding fragment at the 15- and 18-nucleotide exonintron junction (ET) designed by Dr. Andrzej Rafalski (Table 2) and prepared at the Institute of Biochemistry and Biophysics of the Polish Academy of Science (Instytut Biochemii i Biofizyki PAN).

Primer ET 6/18 (Figure 4) yielded the highest total number of bands and included the majority of differentiating bands. Next was the ET 2/18 primer which generated 11 bands in all, $90.9 \%$ of which were differentiating. The other 18-nucleotide primers would generate from 4 to 9 bands of which $49.9 \%$ were polymorphic. In the 15 -nucleotide group, primer ET 32/15 (Figure 5) yielded the highest total number of bands (10). Except for ET 31/15 (0), the remaining primers generated from 3 to 9 bands with the average of $35.1 \%$ of polymorphic bands.

The evaluation of genetic similarity of the cultivars was based on the analysis of 59 DNA fragments obtained from the experiments using semi-specific PCR (Figure 2). The genetic distance coefficients between the tested lines were computed from the experiments using semi-specific PCR and ranged from 0.19 to 0.58 (average 0.40 ).

\section{Discussion}

Similar morphological features of the gerbera cultivars do permit to identify the varieties as the features are too similar

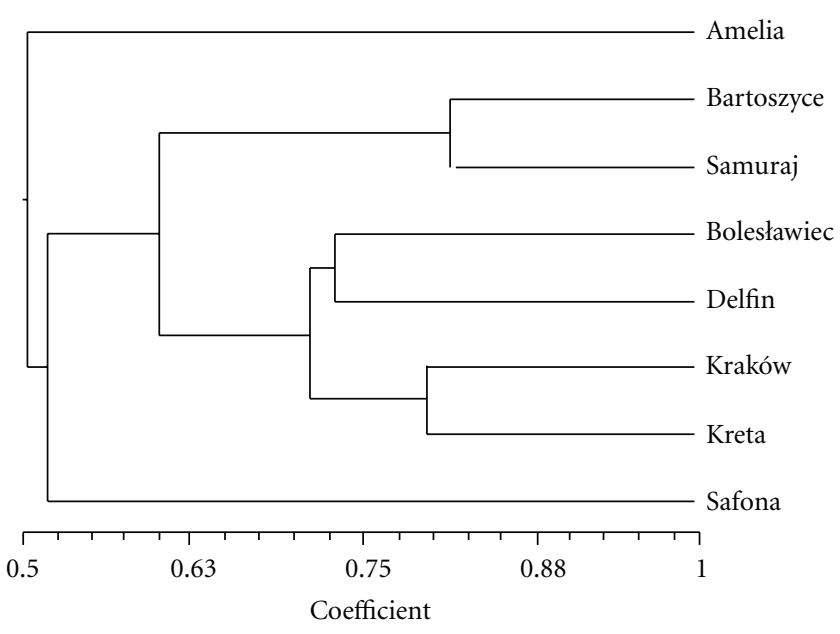

FIGURE 2: Similarity diagram of the G. jamesonii cultivars computed from the mean connections method (UPGMA) and from an analysis of 59 DNA fragments obtained by means of semi-specific PCR.

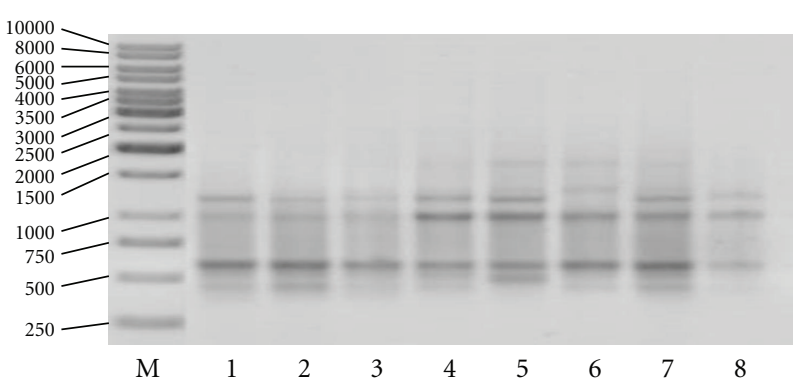

FIGURE 3: The amplification profile generated with the use of D11, from the left: marker (M) of the size $1 \mathrm{~kb}$, G. jamesonii cultivars: 1 Amelia, 2 Bartoszyce, 3 Bolesławiec, 4 Delfin, 5 Kraków, 6 Kreta, 7 Safona, and 8 Samuraj.

between the varieties. Thus, methods based on molecular biology are being more frequently applied, for example, AFLP [10-12], SSR [13], RAPD [4, 14], and semi-specific PCR [8]. Methods such as AFLP and SSR require expensive equipment and reagents [10-13]. The here employed RAPD and semi-specific PCR methods presented in this study are relatively cheaper than the aforementioned alternatives, which may predispose them to being applied in cultivar identification, especially considering the cost and feasibility of analysis [8].

The conducted analyses of RAPD with the use of DNA from eight Polish cultivars of gerbera (Amelia, Bartoszyce, Bolesławiec, Delfin, Kraków, Kreta, Safona, Samuraj) stood out as generating few amplification products. In the present work 70 per cent of the used primers generated bands. Polymorphic bands were generated by 60 percent of the usedin-the-tests primers. Rezende et al. [4] carried out research on G. jamesonii testing 31 primers, of which 21 generated polymorphic bands $(68 \%)$. Similar studies were conducted on gerbera by Chung et al. [7], and the elicited results showed that merely 36 of the 80 primers (45\%) would generate polymorphic bands. 


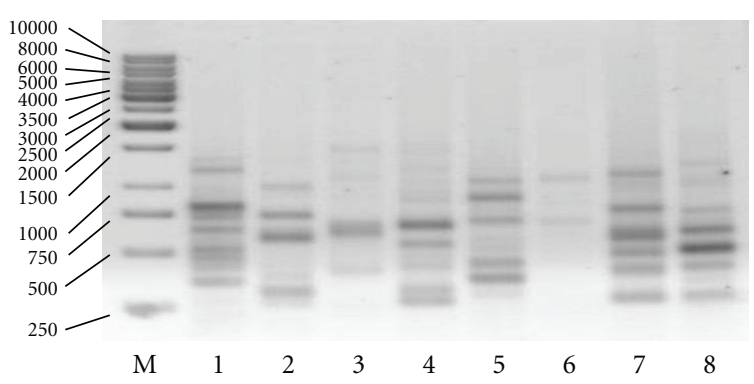

FIGURE 4: Amplification profile generated with the use of the primers ET 6/18, from the left: marker (M) of the size $1 \mathrm{~kb}$, G. jamesonii cultivars: 1 Amelia, 2 Bartoszyce, 3 Bolesławiec, 4 Delfin, 5 Kraków, 6 Kreta, 7 Safona, and 8 Samuraj.

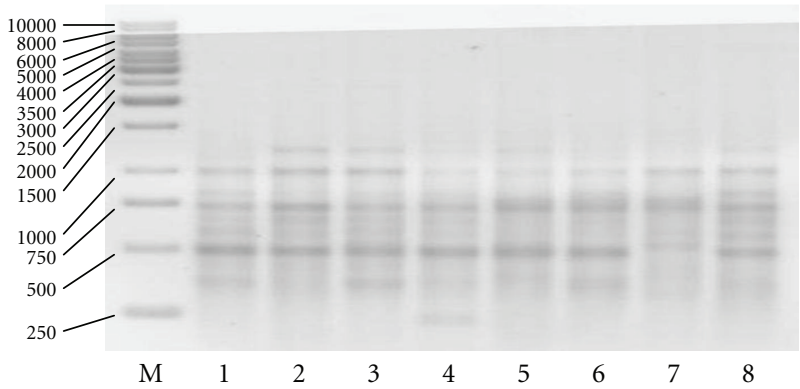

FIgure 5: Amplification profile generated with the use of the primers ET 32/15, from the left: marker (M) of the size $1 \mathrm{~kb}$, G. jamesonii cultivars: 1 Amelia, 2 Bartoszyce, 3 Bolesławiec, 4 Delfin, 5 Kraków, 6 Kreta, 7 Safona, and 8 Samuraj.

Although during the tests of genetic differentiation of gerbera cultivars different RAPD primers generated polymorphic bands, the use of a single primers to identify one lineage proved insufficient, as differentiating bands would show up for several cultivars simultaneously, and to distinguish them other primers had to be used. A similar result was yielded by Rafalski [8] when testing corn lineages.

The method utilizing semi-specific PCR has never been used in research on Gerbera sp. The use of partially specific primers is a relatively new method of investigating the DNA polymorphism. The suggested system is equally simple and quick as the RAPD method. Simultaneously the semi specific primers generate much more complex images of the amplification profiles in comparison to the RAPD method $[8,15]$.

When using the semi-specific PCR with the material from the eight gerbera cultivars (Amelia, Bartoszyce, Bolesławiec, Delfin, Kraków, Kreta, Safona, Samuraj) (Table 2). a polymorphism reaching $100 \%$ was observed, which means that one primer sufficed to distinguish all eight cultivars. The highest number of bands was generated by the 18-nucleotide primers of the ET group, similar results were yielded by Rafalski [8] who applied 15- and 18-nucoeotide primers of the ET group. Most of the used in the present work primers would generate 20 to 30 DNA fragments.

The yielded results served to compute the coefficients of genetic distance between the cultivars. Diagram of Euclidean distances is shown in Figures 1 and 2. The coefficients of genetic distance of the tested gerbera lines computed from the results obtained by means of semi-specific primers of the ET group ranged from 0.19 to 0.58 , although the coefficients of genetic distance between the lines computed from experiments conducted with the use of the RAPD technique ranged from 0.09 to 0.62 . Also in the Rafalski tests carried out on the corn lines [8], higher method sensitivity was achieved by means of semi-specific PCR in comparison to the RAPD technique. In the research on corn, the genetic distance computed from RAPD experiments was 0.19 on average, and 0.38 from multiplications by means of the semi-specific primers. The authors of this paper favor the thesis propounded by Rafalski, in which the PCR system using the semiconservative primers enable a precise measurement of the genetic distance between the lines manifesting significant consanguinity.

\section{Acknowledgment}

One of the authors deeply grateful to Dr. A. Rafalski for his valuable assistance in the semi-specific PCR application and for donation of primers.

\section{References}

[1] T. Orlikowska, "Metody biotechnologiczne w kwiaciarstwie," Zeszyty Naukowe Instytutu Sadownictwa i Kwiaciarstwa, vol. 7, pp. 69-78, 2000.

[2] B. Michalik, "Wykorzystanie biotechnologii w hodowli roślin. Hodowla roślin ogrodniczych u progu XX wieku," Materiały VIII Ogólnopolskiego Zjazdu Naukowego Hodowców Roślin Ogrodniczych, pp. 5-10, 1999.

[3] D. Grzebelus, "Zastosowanie metod biotechnologicznych w hodowli roślin,” in Drukrol, B. Michalik, Ed., pp. 99-115, S.C. w Krakowie, 1996.

[4] R. K. S. Rezende, L. V. Paiva, R. Paiva, A. Chalfun Junior, P. P. Torga, and T. E. Masetto, "Genetic divergence among cultivars of gerbera using RAPD markers," Ciencia Rural, vol. 39, no. 8, pp. 2435-2440, 2009.

[5] T. L. D. Mata, M. I. Segeren, A. S. Fonseca, and C. A. Colombo, "Genetic divergence among gerbera accessions evaluated by RAPD,” Scientia Horticulturae, vol. 121, no. 1, pp. 92-96, 2009.

[6] M. G. Murray and W. F. Thompson, "Rapid isolation of high molecular weight plant DNA," Nucleic Acids Research, vol. 8, no. 19, pp. 4321-4326, 1980.

[7] Y. Chung, H. Kim, K. Kim et al., "Morphological characteristics and genetic variation of gerbera (Gerbera hybrida hort.)," Journal of Plant Biotechnology, vol. 3, pp. 145-149, 2001.

[8] A. Rafalski,, "Semispecyficzny PCR w badaniach genetycznohodowlanych roślin," in Monografie i rozprawy naukowe IHAR Radzików, vol. 23, pp. 1-81, 2004.

[9] M. Nei and W. H. Li, "Mathematical model for studying genetic variation in terms of restriction endonucleases," Proceedings of the National Academy of Sciences of the United States of America, vol. 76, no. 10, pp. 5269-5273, 1979.

[10] S. Khan and W. Spoor, "Use of molecular and morphological markers as a quality control in plant tissue culture," Pakistan Journal of Biological Sciences, vol. 4, pp. 479-482, 2001.

[11] J. De Riek, "Are molecular markers strengthening plant variety registration and protection?" Acta Horticulturae (ISHS), vol. 552, pp. 215-223, 2001. 
[12] J. De Riek, M. Martens, J. Dendauw et al., "The use of fluorescent AFLP to assess genetic conformity of a breeder's collection of R. simsii hybrids," Acta Horticulturae, vol. 508, pp. 99-104, 2000.

[13] S. Rajapakse, D. H. Byrne, L. Zhang, N. Anderson, K. Arumuganathan, and R. E. Ballard, "Two genetic linkage maps of tetraploid roses," Theoretical and Applied Genetics, vol. 103, no. 4, pp. 575-583, 2001.

[14] K. Hamada and M. Hagimori, "RAPD-based method for cultivar-identification of calla lily (Zantedeschia spp.)," Scientia Horticulturae, vol. 65, no. 2-3, pp. 215-218, 1996.

[15] M. Gaweł, I. Wiśniewska, and A. Rafalski, "Semi-specific PCR for the evaluation of diversity among cultivars of wheat and triticale," Cellular and Molecular Biology Letters, vol. 7, no. 2, pp. 577-582, 2002. 

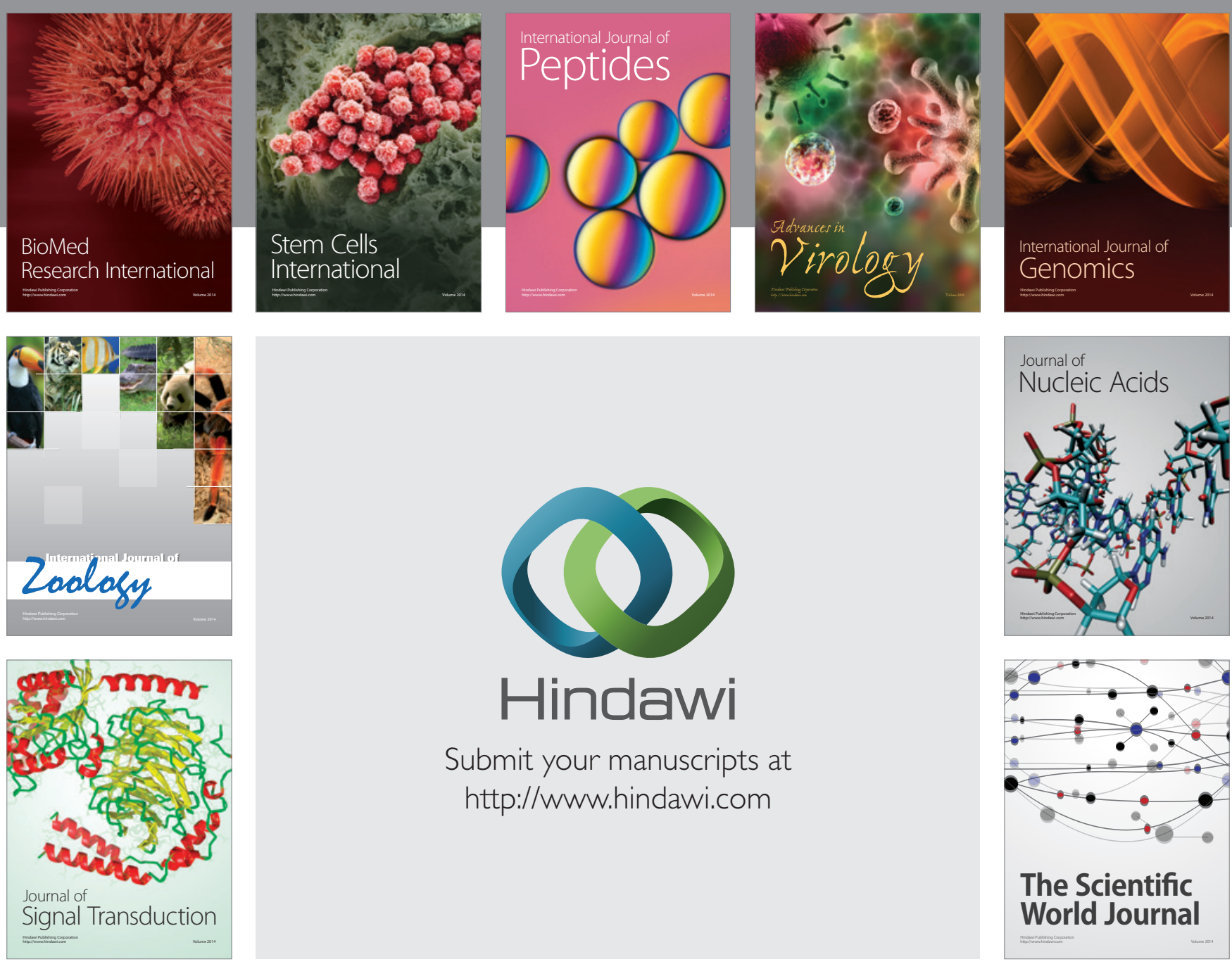

Submit your manuscripts at

http://www.hindawi.com
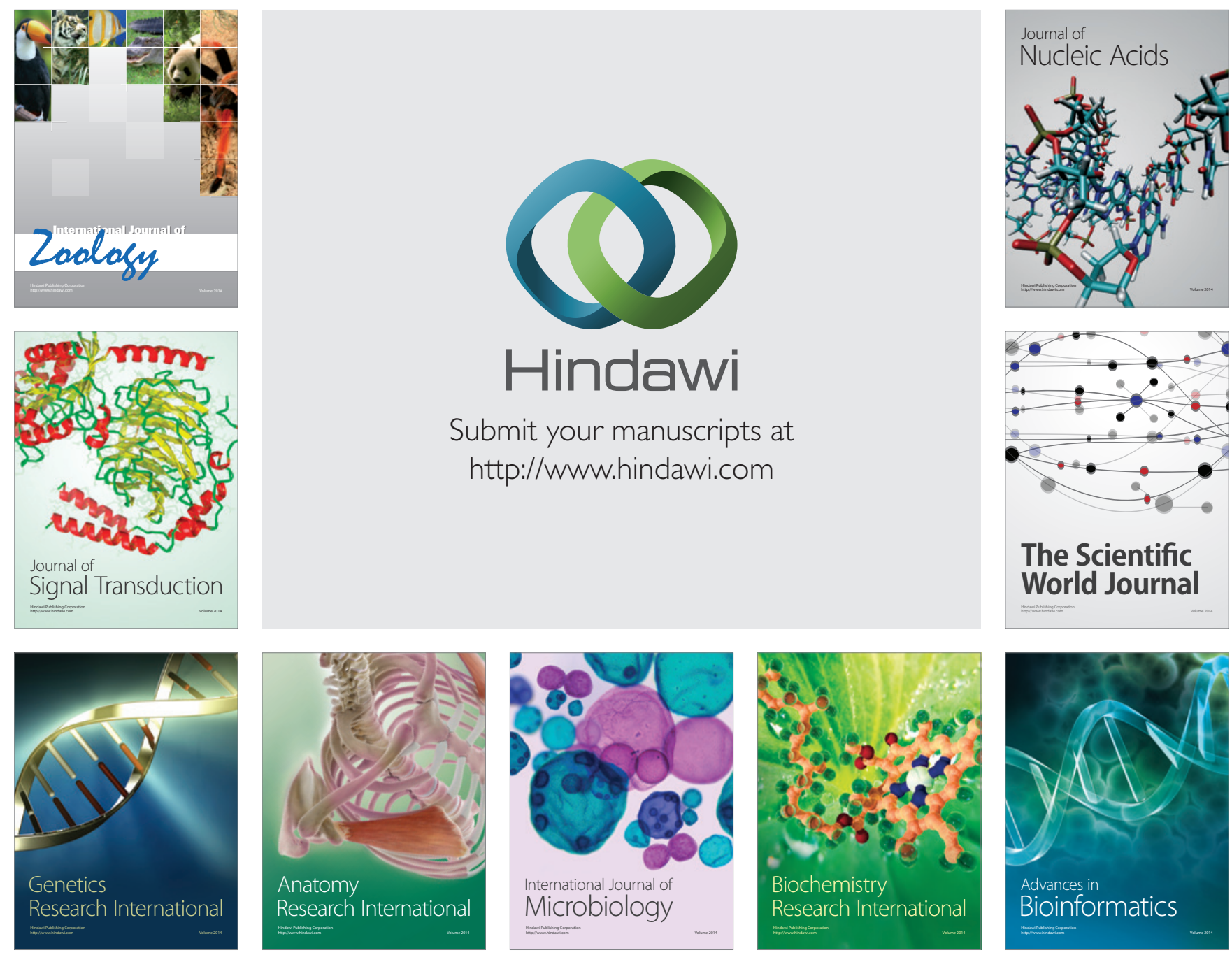

The Scientific World Journal
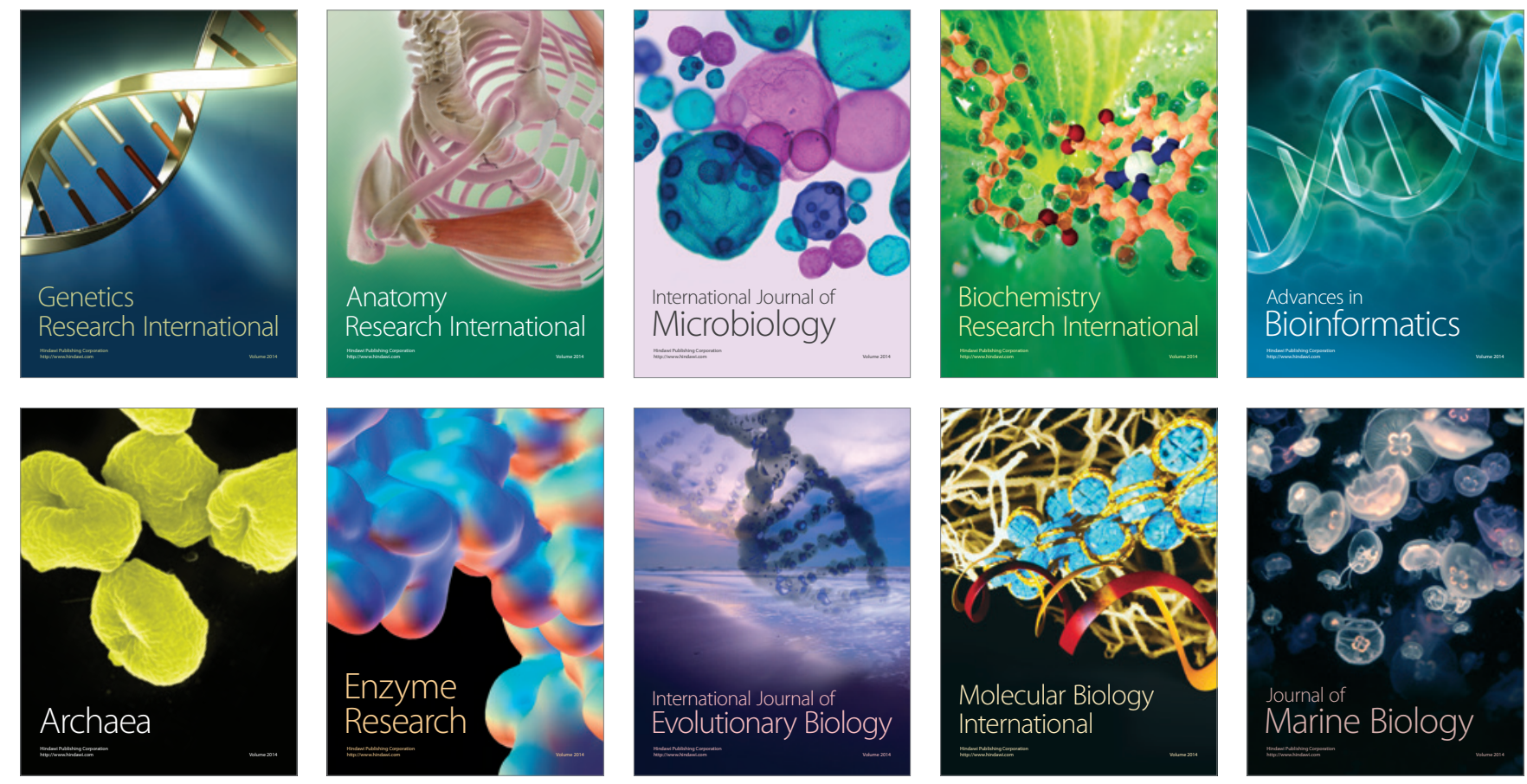